\title{
Kompetensi Individu dan Dukungan Organisasi Terhadap Kinerja Aparat Pengawas Intern Pemerintah (APIP) di Inspektorat Daerah Kabupaten Buleleng
}

\author{
Gusti Ayu Desy Indrayani ${ }^{*}$, Kadek Rai Suwena², I Wayan Suwendra ${ }^{3}$
}

1,2,3 Jurusan Pendidikan Ekonomi Universitas Pendidikan Ganesha Singaraja, Indonesia

\author{
A R T I C L E I N F O \\ Article history: \\ Received 15 May 2018 \\ Received in revised form \\ 13 June 2018 \\ Accepted 15 July 2018 \\ Available online 29 August \\ 2018 \\ Kata Kunci: \\ Kompetensi Individu, \\ Dukungan Organisasi, dan \\ Kinerja \\ Keywords: \\ Individual Competence, \\ Organizational Support, and \\ Performance
}

\begin{abstract}
A B S T R A K
Penelitian ini bertujuan untuk mengetahui pengaruh kompetensi individu dan dukungan organisasi terhadap kinerja Aparat Pengawas Intern Pemerintah (APIP) di Inspektorat Daerah Kabupaten Buleleng. Jenis penelitian ini adalah penelitian kausal. Data dikumpulkan dengan metode kuisioner. Analisis yang digunakan dalam penelitian ini adalah T test, $F$ test dan regresi linier berganda dengan menggunakan SPSS (Statistical Product and Service Solutions) versi 16.0 for Windows. Hasil penelitian menunjukkan, Kompetensi Individu berpengaruh terhadap Kinerja Aparat Pengawas Intern Pemerintah (APIP) di Inspektorat Daerah Kabupaten Buleleng, hal ini ditunjukkan dari nilai t hitung 10.072 $>$ t tabel 2.006 atau nilai signifikansi $0.000<0.05$. demikian pula Dukungan Organisasi berpengaruh terhadap Kinerja Aparat Pengawas Intern Pemerintah (APIP) di Inspektorat Daerah Kabupaten Buleleng , hal ini ditunjukkan dari nilai thitung $8.456>$ t tabel 2.006 atau nilai signifikansi $0.000<0.05$, sedangkan secara simultan Kompetensi Individu dan Dukungan Organisasi berpengaruh terhadap Kinerja Aparat Pengawas Intern Pemerintah (APIP) di Inspektorat Daerah Kabupaten Buleleng, hal ini ditunjukkan dari bahwa nilai Fhitung67.971 $>\mathrm{F}$ tabel4.02 atau nilai signifikansi $0.000<0.05$.
\end{abstract}

A B S T R A C T

This study aims to determine the effect of individual competence and organizational support on the performance of the Government Internal Supervisory Apparatus (APIP) in the Regional Inspectorate of the Buleleng Regency. This type of research is causal research. Data was collected by questionnaire method. The analysis used in this study is $T$ test, $F$ test and multiple linear regression using SPSS (Statistical Product and Service Solutions) version 16.0 for Windows. The results showed, Individual Competence affects the Performance of Government Internal Supervisory Apparatus (APIP) in the Regional Inspectorate of Buleleng Regency, this is indicated from the value of $t$ count $10.072>$ t tabel 2.006 or significance value $0.000<0.05$. Likewise Organizational Support influences the Performance of Government Internal Supervisory Apparatus (APIP) in the Regional Inspectorate of Buleleng Regency, this is indicated by the value of $t$ count hitung8.456 $>t$ tabel2.006 or significance value $0.000<0.05$, while simultaneously Individual Competency and Organizational Support influence Performance Government Internal Supervisory Apparatus (APIP) in the Regional Inspectorate of the Regency of Buleleng, this is indicated by the value of $f$ value $F$ hitung67.971 $>F$ tabel4.02 or significance value $0.000<0.05$.

\footnotetext{
* Corresponding author.

E-mail addresses: gung.eciik1236@gmail.com (Gusti Ayu Desy Indrayani)
} 


\section{Pendahuluan}

Tuntutan dalam pelaksanaan akuntabilitas pada sektor publik terhadap terwujudnya good governace semakin meningkat. Salah satu yang mendukung terciptanya good governance adalah Sumber Daya Manusia (SDM) yang memiliki kemampuan, sikap, pengetahuan, bakat, dan keterampilan. Sumber daya manusia memegang peranaan penting dalam mengembangkan tatanan pemerintahan. Penggerak dari sistem organisasi pemerintah adalah manusia yang ada didalamnya, yaitu pegawai yang bekerja dalam rangka tugas, fungsi dan tanggung jawabnya. Sumber daya manusia yang berkualitas dibutuhkan untuk menyelesaikan pekerjaan yang disediakan oleh suatu instansi atau perusahaan. Menyelesaikan pekerjaan membutuhkan kinerja yang baik sehingga tujuan yang diinginkan dapat tercapai. Jika kinerja karyawan menurun maka akan mempengaruhi hasil pekerjaan mereka. Menurut Bangun (2012: 231) "kinerja adalah hasil kerja yang dicapai oleh karyawan berdasarkan persyaratan pekerjaan". Menurut Faustino Cardosa Gomes (1995:195), mengemukakan, definisi kinerja karyawan sebagai "Ungkapan output, efisiensi, serta efektivitas dan berhubungan dengan produktivitas". Bastian (2006:274) menjelaskan bahwa kinerja adalah gambaran pencapaian pelaksanaan suatu kegiatan/program/kebijaksanaan dalam mewujudkan sasaran, tujuan, misi, visi organisasi. Menurut Robbins (2003), bahwa kinerja adalah sebagai fungsi dari interaksi antara kemampuan dan motivasi. Menurut Hakim (2006:103), mendefinisikan kinerja sebagai hasil kerja yang dicapai oleh individu yang disesuaikan dengan peran atau tugas individu tersebut dalam suatu instansi atau perusahaan pada periode tertentu, yang dihubungkan dengan ukuran nilai atau standar tertentu dari perusahaan atau instansi dimana individu tersebut bekerja. Sementara itu, menurut Payaman J. Simanjuntak (2005) "kinerja karyawan adalah tingkat pencapaian hasil atas pelaksanaan tugas tertentu".

Berdasarkan beberapa pendapat ahli, dapat disimpulkan bahwa kinerja adalah hasil kerja yang diperoleh oleh karyawan dalam menjalankan tugas yang diberikan sesuai dengan periode yang telah ditentukan dari kebijakan lembaga atau perusahaan. Dalam menilai kinerja karyawan ada dimensi dan indikator yang dibutuhkan. Menurut Payaman J. Simanjuntak (2005: 119) bahwa untuk memfasilitasi penilaian karyawan, standar pekerja harus dapat diukur dan dipahami dengan jelas. Pekerjaan dapat diukur melalui 5 (lima) dimensi kuantitas pekerjaan, dimensi ini menunjukkan jumlah pekerjaan yang dihasilkan oleh individu atau kelompok sebagai persyaratan yang menjadi standar kerja. Kualitas kerja, setiap karyawan di perusahaan harus memenuhi persyaratan tertentu untuk dapat menghasilkan pekerjaan sesuai dengan kualitas yang dituntut dari suatu pekerjaan tertentu. Ketepatan waktu, setiap pekerjaan memiliki karakteristik yang berbeda, untuk jenis pekerjaan tertentu harus diselesaikan tepat waktu, karena memiliki ketergantungan pada pekerjaan lain. Kehadiran jenis pekerjaan tertentu membutuhkan kehadiran karyawan dalam melakukannya sesuai waktu yang ditentukan. Kemampuan untuk bekerja sama, tidak semua pekerjaan dapat diselesaikan oleh satu karyawan saja, untuk jenis pekerjaan tertentu mungkin harus diselesaikan oleh dua atau lebih karyawan.

Menurut Payaman J. Simanjuntak (2005: 119) indikator kinerja karyawan yang digunakan adalah Melakukan pekerjaan sesuai dengan target output yang akan dihasilkan oleh individu per satu jam kerja. Melakukan pekerjaan sesuai dengan jumlah siklus aktivitas yang diselesaikan; Melakukan pekerjaan sesuai dengan kemampuan yang dimiliki. Melakukan pekerjaan sesuai dengan persyaratan perusahaan; Selesaikan pekerjaan sesuai dengan deadline yang telah ditentukan. Memanfaatkan waktu proses optimal untuk menghasilkan output yang diharapkan dari perusahaan; Tiba tepat waktu. Melakukan pekerjaan sesuai dengan jam kerja yang ditentukan; Membantu atasan dengan memberikan saran untuk meningkatkan produktivitas perusahaan. Hormati rekan kerja satu sama lain dan bekerja dengan rekan kerja juga. Menurut Payaman J. Simanjuntak(2005), kinerja setiap orang dipengaruhi oleh banyak faktor yang dapat digolongkan pada 3 kelompok, yaitu kompetensi individu, dukungan organisasi, dan dukungan manajemen. Kinerja setiap orang tergantung pada kuantitas dan kualitas dari suatu hasil kerja individu. Kompetensi individu adalah kemampuan dan keterampilan kerja. Indikator-indikator kompetensi individu yang mempengaruhi kinerja pegawai terdiri dari kemampuan dan keterampilan kerja dan motivasi dan etos kerja. Dukungan organisasi, kinerja setiap orang tergantung pada dukungan organisasi. Dalam melakukan tugasnya, pegawai memerlukan dukungan organisasi tempat ia bekerja. Indikator-indikator dukungan kerja pegawai yang mempengaruhi kinerja terdiri dari pengorganisasian, peralatan kerja, lingkungan kerja, serta kondisi dan syarat kerja. Dukungan manajemen, kinerja perusahaan dan kinerja setiap orang juga tergantung pada kemampuan manajerial, para manajerial atau pimpinan. Indikator-indikator dukungan manajemen yang mempengaruhi kinerja pegawai terdiri dari kepemimpinan, koordinasi, dan iklim kerja yang kondusif.. 


\section{Metode}

Jenis penelitian yang digunakan adalah penelitian kausal, dengan pendekatan penelitian kuantitatif. Penelitian kausal merupakan penelitian sebab akibat yang menjelaskan pengaruh antara suatu variabel terhadap variabel lainnya yang digunakan untuk menjawab permasalahan melalui pengujian hipotesis (Sugiyono, 2010 : 56). Variabel pada penelitian ini dibagi menjadi dua bagian yaitu variabel bebas dan variabel terikat. Variabel bebas pada penelitian ini adalah kompetensi individu dan dukungan organisasi, sedangkan variabel terikat pada penelitian ini adalah kinerja pegawai.

Penelitian ini di lakukan di Badan Inspektorat Daerah Kabupaten Buleleng. Populasi dalam penelitian ini adalah seluruh pegawai yang bekerja di Badan Inspektorat Kabupaten Buleleng sebagai pengawas intern pemerintah dengan menggunakan metode sampel jenuh. Sampel jenuh adalah teknik penarikan sampel apabila semua anggota populasi digunakan sebagai sampel. Hal ini sering dilakukan apabila jumlah populasi kurang dari 100" (Suryani dan Hendrayadi, 2015:203). Dalam penelitian ini kriteria yang dimaksud adalah karyawan yang bekerja di Badan Inspektorat Daerah Kabupaten Buleleng, yang berjumlah 56 orang. Sehingga 56 orang diambil sampelnya dalam penelitian Kompetensi Individu dan Dukungan Organisasi tentang Kinerja Karyawan.

Uji Validitas digunakan untuk mengukur instrumen yang berisi pertanyaan terkait dengan variabel yang digunakan. Menurut Arikunto (2006) validitas adalah ukuran menunjukkan tahapan validitas atau stabilitas sesuai dengan instrumen. Instrumen yang valid atau stabil memiliki validitas yang tinggi. Sebaliknya, instrumen yang kurang valid atau tidak stabil berarti validitas rendah. Menurut Sugiyono (2010) bahwa instrumen tersebut valid jika memenuhi kriteria instrumen pengujian validitas menggunakan taraf signifikansi 5\%. Item instrumen dikatakan valid jika $r$ hitung> $r$ tabel maka item instrumen dapat digunakan dalam penelitian. Item item dikatakan tidak valid jika $r$ hitung $<\mathrm{r}$ tabel maka item instrumen tidak dapat digunakan dalam penelitian. Uji reliabilitas dilakukan dengan rumus Cronbach Alpha.

Nilai batas yang digunakan untuk mengevaluasi setiap variabel dapat dilihat pada nilai Alpha Cronbach, jika nilai Alpha> 0,60, maka konstruk pertanyaan yang merupakan dimensi variabel dalam penelitian dapat diandalkan, sedangkan jika nilai Alpha $<0,60$ maka konstruk pertanyaan adalah dimensi variabel penelitian tidak dapat digunakan (Sujarweni, 2015: 199).

Menurut Ghozali (2009) uji normalitas bertujuan untuk menguji apakah dalam model regresi, variabel disruptive atau residual memiliki distribusi normal, seperti yang diketahui bahwa $t$ dan $f$ test mengasumsikan nilai sisa mengikuti distribusi normal. Jika asumsi ini dilanggar maka uji statistik menjadi tidak valid untuk sejumlah kecil sampel. Dalam uji normalitas dapat diuji dengan analisis grafik dan uji statistik.

Analisis grafik adalah salah satu cara termudah untuk melihat normalitas dengan melihat histogram yang membandingkan data observasi dengan distribusi lebih dekat ke distribusi normal tetapi analisis grafik tidak digunakan untuk sampel kecil. Sedangkan analisis statistik menggunakan uji Kolmogrov - Smirnov (KS) yang dapat digunakan untuk menguji normalitas residual. Uji KS dilakukan dengan hipotesis berikut.

HO :residual terdistribusi secara normal

$\mathrm{HA}$ : residual tidak terdistribusi normal

Dalam studi tentang pengaruh Kompetensi Individu dan Dukungan Organisasi terhadap kinerja Aparat Pengawas Intern Pemerintah (APIP) di Inspektorat Daerah Kabupaten Buleleng, menggunakan SPSS (Statistical Product and Service Solutions) versi 16.0 untuk Windows menggunakan teknik analisis data sebagai berikut.

Uji t dilakukan dengan membandingkan t hitung dengan t tabel. Menurut Ghozali (2009) uji statistik t pada dasarnya menunjukkan bagaimana pengaruh satu variabel independen terhadap variabel dependen dengan mengasumsikan konstanta variabel independen lainnya, jika asumsi kesalahan normalitas terpenuhi, maka dapat menggunakan uji t untuk menguji koefisien parsial. dan regresi, nilai signifikansi $>0.05$, maka Ho ditolak dan Ha diterima. Nilai signifikansi $<0.05$, maka Ha diterima dan Ho ditolak.

Uji F dapat dilakukan dengan membandingkan $\mathrm{F}$ hitung dengan $\mathrm{F}$ tabel, jika $\mathrm{F}$ hitung> dari $\mathrm{F}$ tabel, (Ho ditolak Ha diterima). Menurut Ghozali (2009) uji statistik F pada dasarnya menunjukkan apakah semua variabel independen yang termasuk dalam model memiliki efek simultan atau simultan pada variabel dependen. 


\section{Hasil dan pembahasan}

Berdasarkan hasil analisis data yang dilakukan oleh peneliti dalam penelitian untuk mengetahui pengaruh kompetensi individu terhadap kinerja pegawai di Inspektorat Daerah Kabupaten Buleleng menggunakan program analisis SPSS (Statistical Product and Service Solutions) versi 16.0 for Windows. Hasil analisis dapat dilihat pada perhitungan uji t menggunakan taraf signifikansi 5\%. Hasil analisis yang dilakukan pada uji t dapat dilihat pada Tabel 1.

Tabel 1. Hasil Uji t Pengaruh Kompetensi Individu terhadap Kinerja Pegawai

\begin{tabular}{|c|c|c|c|c|c|c|c|}
\hline & \multirow[b]{2}{*}{ Model } & \multicolumn{2}{|c|}{$\begin{array}{l}\text { Unstandardized } \\
\text { Coefficients }\end{array}$} & \multirow{2}{*}{$\begin{array}{l}\text { Standardized } \\
\text { Coefficients } \\
\text { Beta }\end{array}$} & \multirow[b]{2}{*}{$\mathrm{T}$} & & \multirow[b]{2}{*}{ Sig. } \\
\hline & & $\mathrm{B}$ & Std. Error & & & & \\
\hline \multirow[t]{2}{*}{1} & (Constant) & 8.039 & 9.529 & & .844 & .403 & \\
\hline & Kompetensi Individu & .799 & .079 & .808 & 10.072 & .000 & \\
\hline
\end{tabular}

Tabel 1 di atas pada hasil analisis program SPSS (Statistical Product and Service Solutions) versi 16.0 untuk Windows, menunjukkan bahwa nilai thitung 10.072>t tabel 2.006 atau p-value $0,000<0.05$, sehingga dapat disimpulkan dalam mempelajari bahwa H0 ditolak dan Ha diterima dalam penelitian yang dilakukan di Inspektorat Daerah Kabupaten Buleleng, yang berarti ada pengaruh antara kompetensi individu terhadap kinerja pegawai di Inspektorat.

Berdasarkan hasil penelitian data di atas yang dilakukan oleh peneliti dalam penelitian yang dilakukan untuk mengetahui pengaruh Dukungan Organisasi terhadap Kinerja Pegawai di di Inspektorat Daerah Kabupaten Buleleng menggunakan program SPSS (Statistical Product and Service Solutions) versi 16.0 for Windows. Hasil analisis dapat dilihat pada perhitungan uji t menggunakan taraf signifikansi 5\%. Hasil analisis uji t dapat dilihat pada tabel 2.

Table 2. Hasil Uji t Pengaruh Dukungan Organisasi terhadap Kinerja Pegawai

\begin{tabular}{lllllll}
\hline & & \multicolumn{2}{l}{$\begin{array}{l}\text { Unstandardized } \\
\text { Coefficients }\end{array}$} & \multicolumn{2}{l}{$\begin{array}{l}\text { Standardized } \\
\text { Coefficients }\end{array}$} & \\
\cline { 3 - 5 } Model & & B & Std. Error & Beta & t & Sig. \\
\hline 1 & (Constant) & 31.455 & 8.583 & & 3.665 & .001 \\
& Dukungan Organisasi & 1.162 & .137 & .755 & 8.456 & .000 \\
\hline
\end{tabular}

Tabel 2 di atas menunjukkan bahwa nilai t hitung adalah 8.456> t tabel 2.006 atau p-value 0,000 $<0.05$, sehingga dapat

menyimpulkan bahwa Ho ditolak dan Ha diterima, yang berarti ada pengaruh antara dukungan organisasi terhadap kinerja pegawai di inspektorat Daerah Kabupaten Buleleng.

Berdasarkan hasil analisis data yang dilakukan untuk mengetahui pengaruh simultan antara kompetensi individu dan dukungan organisasi terhadap kinerja pegawai menggunakan program analisis SPSS (Statistical Product and Service Solutions) versi 16.0 for Windows. Hasil analisis dapat dilihat pada perhitungan uji $\mathrm{F}$ menggunakan taraf signifikansi 5\%. Hasil analisis uji $\mathrm{f}$ dapat dilihat pada Tabel 3.

Table 3. Hasil Uji F Pengaruh Kompetensi Individu dan Dukungan Organisasi terhadap Kinerja Pegawai

\begin{tabular}{lllllll}
\hline Model & Sum of Squares & df & Mean Square & F & Sig. \\
\hline 1 & Regression & 677.709 & 2 & 338.855 & $67.971 \quad .000^{\mathrm{a}}$ \\
& Residual & 264.219 & 53 & 4.985 & & \\
\multicolumn{1}{l}{ Total } & 941.929 & 55 & & & \\
\hline
\end{tabular}

Tabel 3 di atas menunjukkan bahwa nilai $\mathrm{f}$ hitung $67.971>\mathrm{f}$ tabel 4.02 atau $\mathrm{p}$-value $0,000<0,05$, sehingga dapat disimpulkan bahwa Ho ditolak dan Ha diterima pada penelitian yang dilakukan oleh peneliti terkait dengan variabel yang diteliti, yang artinya ada pengaruh secara simultan antara 
kompetensi individu dan dukungan organisasi untuk kinerja pegawai di Inpektorat Daerah Kabupaten Buleleng.

Besarnya pengaruh kompetensi individu dan dukungan organisasi terhadap kinerja pegawai di inspektorat Daerah Kabupaten Buleleng. peneliti menggunakan program SPSS (Statistical Product and Service Solutions) versi 16.0 untuk Windows, untuk mengetahui besarnya variabel yang diteliti, dapat dilihat pada Tabel 4.

Tabel 4. Koefisien Determinasi (Adjusted R Square)

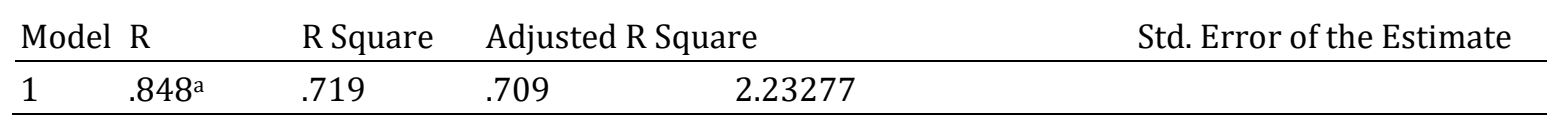

Berdasarkan Tabel 4 diatas, menunjukkan bahwa nilai adjusted R square sebesar 0.709. Hal tersebut dapat disimpulkan bahwa 70,9\% kinerja pegawai pada Inspektorat Daerah Kabupaten Buleleng dipengaruhi oleh kompetensi individu dan dukungan organisasi, sedangkan 29,1\% dipengaruhi oleh faktor lain yang tidak diteliti.

Berdasarkan hasil penelitian untuk mengetahui persamaan regresi antara pengaruh kompetensi individu dan dukungan organisasi terhadap kinerja pegawai di Inspektorat Daerah Kabupaten Buleleng dengan menggunakan analisis koefisien beta. Dapat dilihat pada tabel 5. Koefisien Beta, sebagai berikut,

Tabel 5. Koefisien Beta

\begin{tabular}{|c|c|c|c|c|c|c|}
\hline & & \multicolumn{3}{|c|}{ Unstandardized Coefficients Standardized Coefficients } & \multirow[b]{2}{*}{$\mathrm{t}$} & \multirow[b]{2}{*}{ Sig. } \\
\hline \multicolumn{2}{|c|}{ Model } & $\mathrm{B}$ & Std. Error & Beta & & \\
\hline \multirow[t]{3}{*}{1} & (Constant) & 3.663 & 8.731 & & .420 & 676 \\
\hline & Kompetensi Individu & .543 & .102 & .548 & 5.319 & .000 \\
\hline & Dukungan Organisasi & .564 & .159 & .366 & 3.555 & .001 \\
\hline
\end{tabular}

Tabel 5 diatas berdasarkan hasil analisis SPSS (Statistical Product and Service Solutions) versi 16.0 for Windows, menggambarkan pengaruh kompetensi individu terhadap kinerja pegawai di Inspektorat Daerah Kabupaten Buleleng, adapun hasil persamaan regresi sebagai berikut.

$\mathrm{Y}=3.663+0.543 \mathrm{X}_{1}+0.564 \mathrm{X}_{2}$

Berdasarkan hasil perhitungan di atas, dapat diinterpretasikan bahwa nilai konstan Y (kinerja pegawai) sebesar 3.663 maka hasil dari X1 (kompetensi individu) sebesar 0.543 dan X2 (dukungan organisasi) sebesar 0.564 , bernilai 0 atau konstan. Nilai koefisien regresi yang positif menunjukkan bahwa adanya pengaruh X1 (kompetensi individu) dan X2 (dukungan organisasi) berpengaruh positif terhadap Y (kinerja pegawai). Hal ini menujukkan bahwa peningkatan X1 (kompetensi individu) dan X2 (dukungan organisasi) sebesar satu satuan, sehingga Y (kinerja pegawai) akan mengalami perubahan sebesar nilai koefisien beta masing-masing dikalikan dengan besarnya kenaikan yang terjadi. Misalnya, terjadinya kenaikan X1 (kompetensi individu) sebesar satu satuan maka nilai Y (kinerja pegawai) akan meningkat sebesar 0.543 dan setiap kenaikan X2 (dukungan organisasi) sebesar satu satuan maka nilai Y (kinerja pegawai) akan meningkat sebesar 0.564. Hal ini berarti, ketika kompetensi individu dan dukungan organisasi dalam keadaan baik maka kinerja dari para pegawai akan meningkat, sebaliknya jika kompetensi individu dan dukungan organisasi dalam keadaan kurang baik maka kinerja dari para pegawai akan menurun.

Pengaruh Kompetensi Individu Terhadap Kinerja Pegawai

Berdasarkan hasil penelitian yang dilakukan mengenai pengaruh kompetensi individu terhadap kinerja pegawai di Inspektorat Daerah Kabupaten Buleleng, menunjukkan bahwa kompetensi individu berpengaruh terhadap kinerja pegawai sebesar nilai $t$ hitung $10.072>t$ tabel 2.006 . Artinya semakin baik kompetensi individu pegawai, maka kinerja dari para pegawai akan meningkat, sebaliknya apabila kompetensi individu pegawai kurang baik, maka kinerja dari para pegawai akan rendah. Hal ini didukung oleh teorinya Payaman J. Simanjuntak (2005) yang menyatakan "sumberdaya manusia yang kompeten adalah sumber daya yang memiliki kemampuan keterampilan yang baik serta memadai dalam melakukan pekerjaan dapat mempengaruhi dan meningkatkan kinerja karyawan."

Kompetensi individu dipengaruhi beberapa faktor yaitu kemampuan dan keterampilan serta motivasi dan etos kerja. Kemampuan dan keterampilan kerja setiap orang dipengaruhi oleh kebugaran fisik dan kesehatan jiwa individu yang bersangkutan, pendidikan, akumulasi pelatihan, dan pengalaman 
kerja. Semakin lama waktu yang digunakan seseorang untuk pendidikan dan pelatihan, semakin tinggi kemampuan dan kompetensinya melakukan pekerjaan, dan dengan demikian semakin tinggi kinerjanya, serta pengalaman kerja dapat memperdalam dan memperluas kemampuan kerja. Semakin seseorang melakukan pekerjaan yang sama, semakin terampil dan semakin cepat dia menyelesaikan pekerjaan tersebut. Semakin banyak macam pekerjaan yang dilakukan seseorang, pengalaman kerjanya semakin kaya dan luas, dan memungkinkan peningkatan kinerja. Demikian dengan motivasi dan etos kerja sangat penting mendorong semangat kerja. Dari segi pandangan seseorang atas pekerjaan. Banyak orang yang melihatnya hanya sekedar kesempatan kerja dan sumber penghasilan. Banyak pekerja yang tidak merasakan dan dengan demikian tidak memanfaatkan pekerjaan itu sebagai kesempatan untuk meraih pengalaman kerja, pengetahuan, dan keahlian, kesempatan membangun karier dan sarana untuk aktualisasi diri. Sesuai dengan teori hierarhi kebutuhan dari Abraham Maslow, seseorang akan termotivasi bekerja mencapai kinerja yang tinggi, bila dia memandang pekerjaan itu sebagai kesempatan mengembangkan kemampuan dan karier, serta sebagai sarana aktualisasi diri (Payaman J. Simanjuntak, 2005).

Lebih lanjut penelitian ini didukung oleh hasil penelitian yang dilakukan oleh Riana Dewi (2015) menyatakan bahwa adanya pengaruh secara parsial antara lingkungan kerja terhadap kinerja pegawai dan adanya pengaruh secara simultan antara lingkungan kerja dan disiplin kerja terhadap kinerja pegawai.

Pengaruh Dukungan Organisasi Terhadap Kinerja Pegawai

Berdasarkan hasil penelitian yang dilakukan oleh peneliti mengenai pengaruh dukungan organisasi terhadap kinerja pegawai di Inspektorat Daerah Kabupaten Buleleng, menunjukkan bahwa dukungan organisasi berpengaruh terhadap kinerja pegawai atau nilai dapat dikatakan Ha diterima dan Ho ditolak, sebesar nilai $t_{\text {hitung }} 8.456>t_{\text {tabel }} 2.006$. Artinya apabila dukungan organisasi oleh Instansi atau perusahaan memiliki kualitas yang baik, maka kinerja dari para pegawai tersebut tidak akan terhambat, sebaliknya apabila dukungan organisasi yang disediakan terdapat beberapa kendala seperti kepemimpinan yang kurang baik, lingkungan kerja yang kurang baik, koordinasi yang kurang terhadap sesama pegawai akan membuat terhambatnya kinerja dari para pegawai. Hal ini didukung oleh teorinya Payaman J. Simanjuntak (2005), yang menyatakan bahwa kinerja setiap orang tergantung pada dukungan organisasi yang ditunjukkan dengan indikator-indikator antara lain pengorganisasian, penyediaan sarana dan prasarana kerja, kenyamanan lingkungan kerja serta kondisi dan syarat kerja. Pengorganisasian dimaksudkan untuk memberi kejelasan bagi setiap unit kerja dan setiap orang tentang sasaran yang harus dicapai dan apa yang harus dilakukan untuk mencapai sasaran tersebut. Setiap orang perlu memiliki dan memahami uraian jabatan dan uraian tugas yang jelas serta prosedur melakukan pekerjaan tersebut. Hal ini sejalan dengan penelitian Temasmi (2014) meneliti mengenai Pengaruh komitmen organisasi dan pengendalian intern terhadap kinerja pemerintah daerah menyatakan bahwa pengendalian intern berpengaruh positif terhadap kinerja pemerintah.

Demikian juga penyediaan sarana prasarana dan alat kerja langsung mempengaruhi kinerja setiap orang. Penggunaan peralatan dan teknologi maju sekarang ini bukan saja dimaksudkan untuk meningkatkan kinerja, akan tetapi juga dipandang untuk memberikan kemudahan dan kenyamanan kerja. Kondisi kerja mencakup kenyamanan lingkungan kerja, aspek keselamatan dan kesehatan kerja termasuk ketersediaan alat-alat pelindung. Syarat-syarat kerja mencakup ketentuan kerja, sistem pengupahan dan jaminan sosial, serta keamanan dan keharmonisan hubungan industrial. Hal-hal tesebut mempengaruhi kenyamanan untuk melakukan tugas yyang lebih lanjut mempengaruhi kinerja setiap orang.

Hal-hal tersebut mempengaruhi kenyamanan untuk melakukan tugas yang lebih lanjut mempengaruhi kinerja setiap orang. Syarat-syarat kerja yang memuat hak dan kewajiban setiap pekerja serta kewenangan dan kewajiban akan memberikan kepastian bagi pekerja untuk melaksanakan tugasnya dengan baik dan penuh tanggungjawab. Pemberian kompensasi yang adil dan layak melalui sistem pengupahan akan mendorong setiap pekerja meningkatkan kinerjanya. Perlindungan hak-hak pekerja akan menumbuhkan rasa dihargai dan diperlakukan secara manusiawi daan wajar.

Dukungan organisasi yang kuat dan motivasi dari berbagai aspek menjadikan perilaku pegawai akan terarah sehingga tujuan organisasi akan tercapai. Dengan tercapainya tujuan organisasi dan terpenuhinya kebutuhan pegawai yang tentu saja akan membuat pegawai merasa puas. Apabila dukungan organisasi terpenuhi, maka pegawai akan bekerja lebih baik. Dukungan organisasi yang baik dapat membuat karyawan merasa tenang dan nyaman dalam bekerja.

Pengaruh Kompetensi individu dan Dukungan Organisasi Terhadap Kinerja Pegawai

Berdasarkan hasil penelitian yang dilakukan oleh peneliti mengenai pengaruh kompetensi individu dan dukungan organisasi terhadap kinerja pegawai di Inspektorat Daerah Kabupaten Buleleng menunjukkan bahwa kompetensi individu dan dukungan organisasi berpengaruh secara simultan terhadap kinerja pegawai atau dapat dikatakan Ha diterima dan Ho ditolak, sebesar nilai $\mathrm{F}_{\text {hitung }} 67.971>\mathrm{F}$ 
tabel 4.02. Artinya kompetensi individu dan dukungan organisasi merupakan faktor yang mempengaruhi kinerja pegawai.

Kompetensi individu dan dukungan organisasi merupakan faktor yang sangat penting bagi suatu instansi/perusahaan, dengan baiknya kompetensi individu dan dukungan organisasi maka akan meningkatkan kinerja pegawai. Peningkatan kompetensi individu dari segi kemampuan kerja dilakukan dengan upaya peningkatan aspek-aspek yang mendasari unsur tersebut yakni pengetahuan dan keterampilan kerja individu serta peningkatan motivasi yang mendorong timbulnya kemauan kerja akan mengakibatkan kinerja yang lebih efektif dan efesien dalam menyelesaikan tugas yang diberikan, sebaliknya apabila peningkatan kompetensi individu melalui kemampuan dan keterampilan, serta motivasi kerja yang kurang maka akan mempengaruhi kinerja dari para pegawai (Payaman J. Simanjuntak, 2005).

Selain kompetensi individu, dukungan organisasi juga menjadi salah satu faktor penting yang mempengaruhi kinerja pegawai. Dalam melaksanakan tugasnya, pegawai memerlukan dukungan organisasi tempat ia bekerja. Dukungan organisasi yang baik dalam suatu instansi/perusahaan didukung dalam bentuk pengorganisasian, penyediaan sarana dan prasarana kerja, kenyamanan lingkungan kerja, serta kondisi dan syarat kerja untuk penunjang kegiatan (Payaman J. Simanjuntak, 2005).

Pada Inspektorat Daerah sesuai dengan Laporan Kinerja Instansi Pemerintah (LKJIP) tahun 2017 Kabupaten Buleleng bahwa dari pengukuran kinerja yang dilakukan secara umum pelaksanaan kegiatan sudah optimal untuk mencapai sasaran dan tujuan yang telah ditetapkan, namun tetap diperlukan strategi yang lebih baik untuk meningkatkan kinerja. Tidak kalah pentingnya kapabilitas Inspektorat perlu ditingkatkan dengan mengalokasikan SDM pengawasan yang lebih kompeten karena peran yang diemban sebagai penjaminan kualitas, mengawal dan bertindak sebagai konsultan bagi SKPD lain. Untuk meningkatkan kinerja para pegawai Inspektorat Daerah, dapat dilakukan beberapa upaya yakni dengan cara meningkatkan kemampuan dan keterampilan para pegawai, memberikan pendidikan dan pelatihan, menambah wawasan atas pekerjaan yang dilaksanakan pegawai, motivasi kerja pegawai, penyediaan tempat dan lingkungan kerja yang nyaman, aman, dan sehat, didukung oleh penyediaan kelembagaan, peralatan dan sarana perlindungan keselamatan dan kesehatan kerja, penyediaan kondisi dan syarat kerja termasuk penghargaan atas pekerjaan yang telah dilaksanakan pegawai, memberi peluang bagi instansi dan pekerja membangun hubungan industrial yang aman dan harmonis, termasuk kesempatan berorganisasi untuk merumuskan perjanjian kerja bersama. Tentunya dengan peran seperti ini kualitas dan kuantitas Inspektorat Daerah seharusnya jauh lebih baik dibandingkan dengan SKPD lainnya. Hal ini didukung oleh teorinya Payaman J. Simanjuntak (2005:1) yang menyatakan, bahwa kinerja adalah tingkat pencapaian hasil atas pelaksanaan tugas tertentu dengan menyelesaikan pekerjaan sesuai dengan deadline yang telah ditentukan dan memanfaatkan waktu pengerjaan secara optimal untuk menghasilkan output yang diharapkan oleh perusahaan atau instansi

\section{Simpulan dan saran}

Berdasarkan hasil penelitian dan pembahasan yang telah di bahas pada bab sebelumnya terkait pengaruh kompetensi individu dan dukungan organisasi terhadap kinerja Aparat Pengawas Intern (APIP) di Inspektorat Daerah Kabupaten Buleleng, maka dapat disimpulkan Kompetensi Individu berpengaruh terhadap Kinerja Aparat Pengawas Intern (APIP) di Inspektorat Daerah Kabupaten Buleleng, disebabkan nilai t hitung $4.886>\mathrm{t}$ tabel 1.992 atau signifikansi $0.000<0.05$. Dukungan Organisasi berpengaruh terhadap Kinerja Aparat Pengawas Intern (APIP) di Inspektorat Daerah Kabupaten Buleleng, disebabkan nilai t hitung $7.604>\mathrm{t}$ tabel 1.992 atau signifikansi $0.000<0.05$. Kompetensi Individu dan Dukungan Organisasi berpengaruh secara simultan di Inspektorat Daerah Kabupaten Buleleng, disebabkan nilai f hitung 32.247> f tabel 3.10 atau signifikansi $0.000<0.05$.

Berdasarkan simpulan diatas, maka dapat dikemukakan saran Bagi Badan Inspektorat Daerah Kabupaten Buleleng agar lebih agar meningkatkan pelatihan dan pendidikan penjenjangan agar dapat menunjang kemampuan dan keterampilan para pegawai. Bagi Badan Inspektorat Daerah Kabupaten Buleleng agar lebih memperhatikan dan meningkatkan dukungan organisasinya, dari segi pengorganisasian, penyediaan sarana dan prasarana kerja, kondisi kerja yang mencangkup kenyamanan lingkungan kerja serta memberikan penghargaan atas pelaksanaan tugas dari setiap pegawai demi peningkatan kinerja yang baik. Bagi peneliti selanjutnya, apabila ingin meneliti variabel kompetensi individu dan dukungan organisasi terhadap kinerja pegawai diharapkan untuk mengembangkan penelitian ini dengan populasi dan sampel yang lebih luas. 


\section{Daftar Rujukan}

Arikunto, Suharsimi. 2006. Prosedur Penelitian Suatu Pendekatan Praktik. Jakarta: Rineka Cipta.

Bangun, Wilson. 2012. Manajemen Sumber Daya Manusia. Jakarta: Erlangga. Cetakan Kedua. Jakarta:Bumi Aksara. Edisi 2. Yogyakarta:BPFE

Bernandus, Beda Keda. 2015. "Pengaruh Kompetensi Individu, Dukungan Organisasi dan Dukungan Manajemen Terhadap Kinerja Pegawai Negeri Sipil di Dinas Pendidikan Pemuda dan Olahraga Kabupaten Flores Timur". Tesis. Universitas Terbuka.

Gozali, Imam. 2009. Ekonometrika. Semarang: Universitas Diponegoro.

Handoko, Hani. T. 2005, Manajemen Personalia dan Sumber Daya

Hasibuaan, Melayu S.P. 2000. Manajemen Sumber Daya Manusia. Edisi Revisi.

Jasman, Andi Mattulada Amir, Mohammad Iqbal. 2016. Pengaruh Kompetensi, Independensi Dan Etika Terhadap Kinerja Aparat Pengawas Intern Pemerintah (Apip) Inspektorat Daerah Kabupaten Parigi Moutong. Jurnal Katalogis, Volume 4 Nomor 4, April 2016 hlm 14-24.

Kemala, Dian. 2013. Pengaruh Pemahaman Prinsip-Prinsip Good Governance, Pengendalian Intern, dan Komitmen Organisasi terhadap Kinerja Sektor Publik pada Pemerintah Kabupaten Rokan Hilir. EJurnal Jurusan Akuntansi Universitas Riau. Pekanbaru.

Mangkuprawira, TBS \& Hubies. 2007. Manajemen Mutu Sumber Daya Manusia. Bogor: Ghalia Indonesia.

Mardiasmo. 2005. Perwujudan Transparasi dan Akuntabilitas Publik Melalui Akuntansi Sektor Publik: Suatu Sarana Good Governance. Jurnal Akuntansi Pemerintah.

Meriem, Temasmi. 2014. Pengaruh Komitmen Karyawan dan Pengendalian Intern terhadap kinerja Pemerintah Daerah di Kota Pasuruan . Jurnal Mahasiswa FEB Universitas Brawijaya.

Muhammad, Muslim.2015. Pengaruh Kompetensi, Etos Kerja, dan Dukungan Organisasi Terhadap Kinerja Kantor Kesyahbandaran dan Otoritas Pelabuhan Malahayati". Tesis. Universitas Syiah Kuala.

Ombudsman, Publikasi Hasil Survey Kepatuhan Tahun 2017. Artikel, Dani Marsa Ariaputri.

Panjaitan, Vetty Rebecca TH. 2015. Pengaruh Pengendalian Intern, Kompetensi Sumber Daya Manusia, Komitmen Organisasi Dan Budaya Organisasi Terhadap Kinerja Bagian Keuangan (Studi Pada Skpd Kota Dumai). Jom FEKON Vol. 2 No. 2.

Payaman J. Simanjuntak, 2005. Manajemen dan Evaluasi Kinerja. Edisi 3. Penerbit Fakultas Ekonomi Universitas Indonesia.

Peraturan Bupati Buleleng Nomor 70 Tahun 2014 tentang Tugas Pokok dan Fungsi Inspektorat Kabupaten Buleleng.

Peraturan Menteri Negara Pendayagunaan Aparatur Negara Nomor: PER/05/M.PAN/03/2008 tentang Standar Audit Aparat Pengawasan Intern Pemerintah.

Robbins SP, dan Judge 2008. Perilaku Organisasi Buku 2. Jakarta:Salemba.

Samsi, Nur., Riduwan, Akhmad dan Suryono, Bambang. 2013. Pengaruh pengalaman kerja, independensi, dan kompetensi terhadap kualitas audit etika auditor sebagai variabel pemoderasi. Jurnal Ilmu dan Riset Akuntansi. Vol.1, pp. 4-17.

Sedarmayati. 2009. Sumber Daya Manusia dan Produktivitas Kerja. Bandung: CV Mandar Maju. 
Siswanto, Bedjo. 2003. Manajemen Tenaga Kerja, Rancangan dalam Pendayagunaan dan Pengembangan Unsur Tenaga Kerja, Bandung. Penerbit Sinar Baru.

Sujarweni, Wiratna. 2015. SPSS Untuk Penelitian. Yogyakarta: Pustaka Baru Press.

Sugiyono. 2010. Metode Penelitian Pendidikan. Bandung: Alfabeta.

2012. Metode Penelitian Kuantitatif Kualitatif dan R\&D. Bandung: Alfabeta.

Undang-undang Republik Indonesia Nomor 32 Tahun 2004 dan Undang-undang Nomor 25 Tahun 1999 Tentang Pemerintah Daerah.

Yogi, Gumilar. 2017. "Pengaruh Dukungan Organisasi, Kompetensi, Objektivitas dan Integritas Terhadap Kinerja Aparat Pengawas Intern Pemerintah (Studi Empiris pada Kantor Pusat BPKP)". Skripsi. Universitas Malang 